\title{
Effect of Some Herbs in Boiler Diets on Blood Proteins and Lipids
}

\author{
Hind A. A. Elagib ${ }^{1}$, Khalid M Elamin ${ }^{2 *}$, Saadia .A. Abbas ${ }^{1}$ \\ ${ }^{I}$ (Department of Poultry production, Faculty of Animal Production, University of Khartoum) \\ ${ }^{21}$ Department of Genetics and Animal Breeding, Faculty of Animal Production, University of Khartoum)
}

\begin{abstract}
The present study was conducted to investigate the effect of feeding some herbs on blood proteins and lipids. Sweet rush, Parsley, carrot leaves and onion were incorporated in four diets as $2 \%$ of the basal diet which were used together with a control diet (basal diet) and a diet contained antibiotic doxystin) as experimental diets. Two hundred and forty one day old (cobb) broilers were used in $6 \times 4$ design. Total protein, albumin, globulin, cholesterol, high density lipoprotein $H D L$, low density lipoprotein $L D L$, and triglyceride were measured. Results revealed that the total protein level was high $(p<0.05)$ in the diets contained carrot leaves, Parsley (bagdonis) and those fed onion supplemented diet. Treatments significantly ( $P \leq 0.05)$ affect blood albumen the highest value for blood albumen was recorded in onion treatment whereas the lowest value was recorded in sweet rush. Globulin was not affected by different treatments. Barsely and sweet rush resulted in low cholesterol level, high level observed in Allium cepa (onion) group, antibiotic and the control group . Carrot leaves and antibiotic resulted in high level of HDL and low level HDL in bagdonis fed group. Lemongrass (Sweet rush) recorded low level of low density lipoprotein while high level was observed in the group fed Allium cepa. Triglyceride was not affected by different treatments. It is concluded that herbs had good effect on total protein, albumin, $H D L$, it decreases cholesterol, and LDL, but triglyceride was not affected by herbs.
\end{abstract}

Key words: Blood herbs, protein, cholesterol, triglyceride,

\section{Introduction}

Diet in animals has been appreciated as one of the vital factors that affect health maintenance and prevent occurrence of many disease [1]. Feed additives, natural and chemical are important materials that used to improve the efficiency of feed utilization and general animal performance [2]. However, the use of chemical products especially antibiotics and hormones may cause unfavorable effects. Old drug industry depend on raw material of plant origin (herbs or their extract) which was proved save but many synthesized chemicals are recorded to be hazardous to both man and animals [2]. In order to minimize the harmful effect of the synthetic additives now a day's attention to natural plants is consider.

Parsley (Petroselinium crispum) is an important culinary herb that is native to the Mediterranean areas and it is used in food, cosmetic, perfume and pharmaceutical industries [3]. Parsley was reported to have many medicinal attributes, like antimicrobial [4], laxative [5] and antioxidant [6]. Parsley had been used to treat nose bleeding, to regulate blood pressure, to treat eczema, knee ache, impotence [7]). Its seeds are used as diuretic and the hypoglycemic activity was shown by [8].

[9] found that broilers receiving $30 \mathrm{~g} / \mathrm{kg}$ onion had a significantly higher HDL and lower triglyceride concentrations . Lemongrass (Cymbopogon citrates) is a tall grass of more than fifty species and it is native to tropical and subtropical countries [10] .The biologically active ingredient of it is citrals that constitute more than 75\% of it essential olis [11].

Lemongrass is rich in citral which is an industrial ingredient (perfumes and pharmaceutical) and in bioactive compounds (Flavonoids and vitamin C). These Natural flavonoids are antioxidant, anti-carcinogenic and anti-inflammatory as they act as lipid anti-peroxidant [12]). Fresh carrot contains about $10 \%$ crude proteins, $1.4 \%$ ether extract and up to $60 \%$ sugars, mostly sucrose (on DM basis). The objective of this experiment was to evaluate the effects of feeding different herbs as natural feed additive compared with antibiotic on blood biochemistry.

\section{The experimental animals}

\section{Material and methods}

Two hundred and forty, one day old, white broilers (Cobb strain) obtained from a commercial company and reared in Faculty of Animal production, poultry unit. The birds were divided into six groups each group replicated four times with ten birds per replicate.

Feed and water was provided ad libitum, light was provided for 24 hours per day. Six dietary treatments were fed to the birds in two phases starter and finisher diet. The control group fed basal diet, the second group fed the basal diet plus antibiotic as 5\% (doxystin). The third, fourth, fifth and the six group were fed basal diet and $2 \%$ of sweet rush, Parsley, carrot leaves and onion respectively (table 1).

DOI: 10.9790/2380-0910016164 www.iosrjournals.org $\quad 61 \mid$ Page




\section{The preparation of the herbs}

The herbs used in the experiment were purchased from Khartoum local market then cleaned, dried under shade and powdered. The antibiotic used was Doxystin which contains: Doxycycline $\mathrm{HCl} 50 \mathrm{mg}$ and Colistin sulfate as 400000 IU.

\section{Blood collection}

At slaughter the blood samples were collected from the birds into clean tubes. The serum was separated after centrifugation at 3000 r.p.m for 5 minutes, collected into plain containers.

\section{Biochemical estimations}

Serum samples have been collected at 42 day of age for the estimation of total protein, albumin and total globulins. The serum total protein concentration was determined using Biuret reagent method as described by [13]. The serum albumin concentration was determined using modified Bromocresol green colorimetric method as described by [14]

\section{Serum Lipid estimation}

Serum samples were subjected for the determination of lipid content including: total cholesterol, HDL, LDL, Triglyceride. An enzymatic method which measures the total cholesterol concentration in the serum was used for estimation of the cholesterol concentration [15].

The precipitation method described by [16] was used to determine high density lipoprotein-cholesterol (HDLc). The low density lipoprotein-cholesterol (LDL-c) in $(\mathrm{mg} / \mathrm{L})$ was calculated by applying the following formula

LDL cholesterol $=$ Total cholesterol - Triglycerides $/ 5$ - HDL cholesterol

The triglycerides (TG) were determined according to the enzymatic colorimetric method described by [17]

\section{Statistical analysis}

The data were analyzed by one way ANOVA procedure according to SPSS computing software program. Each test was conducted at $5 \%$ level of significance.

Table (1): Composition of the basal diet fed to the experimental chicks.

\begin{tabular}{|l|l|l|l|l|}
\hline As percentage & $\begin{array}{l}\text { Starter(1- } \\
\text { 3WKS)Control }\end{array}$ & $\begin{array}{l}\text { Finisher (4-6 WKS) } \\
\text { Control }\end{array}$ & $\begin{array}{l}\text { Starter(1- } \\
\text { 3WKS)herbs }\end{array}$ & $\begin{array}{l}\text { Finisher } \\
\text { WKS) herbs }\end{array}$ \\
\hline sorghum & 65.10 & 66.50 & 63.10 & 64.50 \\
\hline Groundnut meal & 18.7 & 13.5 & 18.7 & 13.5 \\
\hline Sesame meal & 10.00 & 12.70 & 10.00 & 12.00 \\
\hline superconcentrate & 5.00 & 5.00 & 5.00 & 5.00 \\
\hline Limestone & 0.90 & 0.90 & 0.90 & 0.90 \\
\hline Salt & 0.25 & 0.25 & 0.25 & 0.25 \\
\hline lysine & 0.04 & 0.06 & 0.04 & 0.06 \\
\hline methionine & 0.01 & 0.01 & 0.01 & 0.01 \\
\hline Vegetable oil & 0.00 & 1.08 & 0.00 & 1.08 \\
\hline herbs & 0.00 & 0.00 & 2.00 & 2.00 \\
\hline
\end{tabular}

*Broiler Super concentrate contains (\%): CP 40, CF 1.5, ME 2122Kal/kg, fat 3,Lysine13.5, Methionine 5.9, Methionine+cystine6.25,P 4.6, Ca 6.8, Na 1.5.

Vitamins supplied per Kg of diet: Vit. A, 250000 IU; Vit. D3, 60000 IU; Vit. E, 800 mg; Vit. K3,60 mg; Vit. B1, 30mg; Vit. B2, $100 \mathrm{mg}$; Vit. B6, $50 \mathrm{mg}$; Vit. B12, $300 \mathrm{mg}$; Vit. C, $4000 \mathrm{mg}$; Niacin, 800mg; Folic acid,30mg; Biotin, 30mg;Choline chioride,3000mg; Copper, $30 \mathrm{mg}$; Iron, 100mg; Manganese, 160mg; Zinc,100mg; Iodine,1.3mg; Selenium, 5mg; Cobalt, 1.2mg; Fytase enzyme, 15000; Antioxidant.

\section{Results}

Table 2. shows that the overall total protein, albumen and globulin content of blood in broilers at 42 days were $3.13 \pm 0.35,1.62 \pm 0.07$, and $1.51 \pm 0.34 \mathrm{~g} / \mathrm{dl}$ respectively. On the other hand, the overall mean of cholesterol, high lipid, low lipid and triglycerides were 279.70 $\pm 51.84,85.59 \pm 9.09,122.65 \pm 12.36$ and $49.55 \pm 6.52 \mathrm{mg} / \mathrm{dl}$, respectively.

Table (2) Overall means and standard errors of broilers blood proteins and lipids

\begin{tabular}{|l|l|}
\hline Traits & $\mathrm{M} \pm \mathrm{SE}$ \\
\hline Total protein $(\mathrm{g} / \mathrm{dl})$ & $4.32 \pm 0.46$ \\
\hline Albumen $(\mathrm{g} / \mathrm{dl})$ & $1.69 \pm 0.06$ \\
\hline Globulin $(\mathrm{g} / \mathrm{dl})$ & $2.63 \pm 0.47$ \\
\hline Cholesterol $(\mathrm{mg} / \mathrm{dl})$ & $238.82 \pm 15.92$ \\
\hline
\end{tabular}


Effect of Some Herbs in Boiler Diets on Blood Proteins and Lipids

\begin{tabular}{|l|l|}
\hline High Lipids $(\mathrm{mg} / \mathrm{dl})$ & $95.41 \pm 7.31$ \\
\hline Low Lipids $(\mathrm{mg} / \mathrm{dl})$ & $130.44 \pm 13.38$ \\
\hline Triglycerides $(\mathrm{mg} / \mathrm{dl})$ & $49.69 \pm 7.60$ \\
\hline
\end{tabular}

Table 3 shows the effects of different herbs on the various traits studied. The highest values of total protein were reported in birds fed diets contained carrot leaves, Parsley (bagdonis) and those fed onion containing diet, with no significant difference from the group fed antibiotic which range from ( $5.9 \pm 1.12$ $2.9 \pm 1.12 \mathrm{~g} / \mathrm{dl})$. However, the low significant value $(\mathrm{P} \leq 0.05)$ was reported in diet containing sweet rush.

Treatments had significant $(\mathrm{P} \leq 0.05)$ effects on albumin content. Birds fed the control diet, antibiotic, parsley and carrot leaves were not significantly $(\mathrm{P} \geq 0.05)$ different in their blood albumin level.

The albumin level in the blood of birds fed Onion was significantly $(\mathrm{P} \leq 0.05)$ different from those fed sweet rush. High value was recorded for onion containing diet, low value in birds fed sweet rush. The albumin level range was from $2.01 \pm 0.15$ to $1.24 \pm 0.15 \mathrm{~g} / \mathrm{dl}$.

Table (3) Effect of different herbs on protein and lipid profile

\begin{tabular}{|l|l|l|l|l|l|l|}
\hline $\begin{array}{l}\text { Treatment } \rightarrow \\
\text { Traits } \downarrow\end{array}$ & Control & Antibiotic & $\begin{array}{l}\text { Cymbogon proximus } \\
(\text { Sweet rush) lemongrass }\end{array}$ & $\begin{array}{l}\text { Parsley } \\
\text { bagdonis }\end{array}$ & Carrot leaves & Allium cepa (onion \\
\hline Total Protein $(\mathrm{g} / \mathrm{dl})$ & $2.95^{\mathrm{ab}} \pm 1.12$ & $5.33^{\mathrm{ab}} \pm 1.12$ & $2.11^{\mathrm{b}} \pm 1.12$ & $5.74^{\mathrm{ab}} \pm 1.12$ & $5.90^{\mathrm{a}} \pm 1.12$ & $3.91^{\mathrm{ab}} \pm 1.12$ \\
\hline Albumin(g/dl) & $1.89^{\mathrm{a}} \pm 0.15$ & $1.76^{\mathrm{a}} \pm 0.15$ & $1.24^{\mathrm{b}} \pm 0.15$ & $1.53^{\mathrm{ab}} \pm 0.15$ & $1.71^{\mathrm{ab}} \pm 0.15$ & $2.01^{\mathrm{a}} \pm 0.15$ \\
\hline Globulin(g/dl) & $1.06 \pm 1.14$ & $3.59 \pm 1.14$ & $0.89 \pm 1.14$ & $4.22 \pm 1.14$ & $4.19 \pm 1.14$ & $1.89 \pm 1.14$ \\
\hline Cholesterol(mg/dl) & $277.3^{\mathrm{ab}} \pm 39.01$ & $282.90^{\mathrm{a}} \pm 39.01$ & $155.84^{\mathrm{b}} \pm 39.01$ & $145.24 \pm 39.01$ & $268.61^{\mathrm{ab}} \pm 39.01$ & $303.03^{\mathrm{a}} \pm 39.01$ \\
\hline High density Lipoproteins $(\mathrm{mg} / \mathrm{dl})$ & $166.75 \mathrm{a} \pm 17.91$ & $123.83^{\mathrm{ab}} \pm 17.91$ & $56.43^{\mathrm{cd}} \pm 17.91$ & $46.03^{\mathrm{d}} \pm 17.91$ & $111.15^{\mathrm{ab}} \pm 17.91$ & $68.26^{\mathrm{bcc}^{\mathrm{cd}} \pm 17.91}$ \\
\hline low density Lipoproteins $(\mathrm{mg} / \mathrm{dl})$ & $103.52^{\mathrm{ab}} \pm 32.78$ & $152.26^{\mathrm{ab}} \pm 32.78$ & $88.44^{\mathrm{b}} \pm 32.78$ & $95.93^{\mathrm{ab}} \pm 32.78$ & $142^{\mathrm{ab}} 23 \pm 32.78$ & $200.34^{\mathrm{a}} \pm 32.78$ \\
\hline Triglycerides(mg/dl) & $35.03 \pm 18.62$ & $34.34 \pm 18.62$ & $63.39 \pm 18.62$ & $30.19 \pm 18.62$ & $76.23 \pm 18.62$ & $58.87 \pm 18.62$ \\
\hline
\end{tabular}

Means in same raw with different letters are significantly different $(\mathrm{P} \leq 0.05)$

There were no significant differences between birds in all treatments for blood globulin contents. The highest level of globulin content was obtained by birds fed Parsley and carrot leaves.

Lower cholesterol level was observed in birds fed diet supplemented with barsely followed by sweet rush in contrast high level was obtained by birds fed Allium cepa (onion) and the group fed antibiotic and the control group.

High level of high density lipoprotein was found in the group fed antibiotic and the group fed carrot leaves followed by allium Cepa, barsely,sweet rush and the lower level in the group fed baresly.

High level of Low density lipoprotein was observed in the group fed Allium cepa (onion) as compared to the group fed Cymbogon proximus (Sweet rush) lemongrass which recorded low level. There was no difference from the control group and those fed antibiotic.

Treatment effects did not significantly affect blood Triglycerides level, however, numerical low values observed in group fed parsely and antibiotic with no difference from control group was found.

\section{Discussion}

The different herbs used in this study which were added to diet to evaluate its action on protein and lipid profile as compared with antibiotic. In this study serum level of total protein was high in birds fed carrot leaves, Parsley (bagdonis) and those fed onion containing diet, and also antibiotic fed group.

Albumin level was not significant different between different treatments except for the group fed sweet rush which recorded significant lower level compared to control and group fed antibiotic.[18] ) found that Barsely resulted in significant increase in blood plasma total protein, albumen. In this study the globulin was not affected by the different treatments this result agreed with [19] who observed no effect of parsley and basil seeds on globulin fraction.

In this study triglyceride level was increased numerically as Allium cepa (onion), Carrot leaves and Cymbogon proximus (Sweet rush) lemongrass were added to the diet . In contrast parsely decrease triglyceride level. [20] reported that the herbal mixture supplement decreased the blood serum cholesterol and triglyceride levels at $7(\mathrm{P}<0.001)$ and at 52 weeks $(\mathrm{P}<0.05)$ of age in layers were added to the diets.

[18] found that Barsely resulted in significant increase in blood plasma total protein, albumen, globulin, HDL, decrease in total cholesterol, triglycerides, LDL, VLDL and creatinine in comparison to control group.

In this study cholesterol level was decreased as Cymbogon proximus (Sweet rush) lemongrass and parsley were added to the diet compared to the control group and the group fed antibiotic. This result confirm the result obtained by [19] who found that parsley and basil seeds did to affect the serum total protein, albumin, globulin, albumin/globulin ratio and glucose contents, but serum cholesterol was significantly reduced . Also,this result agree with [18]) who reported decrease in total cholesterol when parsely was added to the diet. 
[21] found that the birds fed diet containing mixture of thyme and parsley resulted in a reduced serum cholesterol

In this study high level of cholesterol was obtained by birds fed Allium cepa (onion) and the group fed antibiotic and the control group. This result disagrees with the result obtained by [8] and [22]. [22] found that $3 \%$ onion powder reduced blood lipids, lipid peroxides and cholesterol. Sklan et al. (1992) did not observe any effect of onion on hepatic cholesterol. This discrepancy in the result can be attributed to the different strain, and the different type of onion used.

[23] found that group fed herbs alfa alfa had the lowest cholesterol level, serum total cholesterol, Triglycerides and LDL concentration compared to the control group but there was no effect on glucose

and HDL in all groups. This may confirm the report of [24] who suggested that the cholesterol level of blood can be decreased due to high level of fibres which can increase the excretion of bile.

[25] attributed the reduction in serum cholesterol and triglyceride in chicks is substances like carvacrol and tymol which are present in herbs. The cholesterol level of blood can decrease due to high level of fibers which can increase the excretion of bile [24].

In conclusion, it is suggested that the dietary inclusion of herbs in broiler diet can alternate the antibiotic supplementation as it had good medicinal effect on blood protein and lipid, total protein , HDL increase by carrot leaves, albumin increase by barsely, and sweet rush decrease cholesterol, and LDL.

\section{References}

[1]. T Finkel and J Halbrook, Oxidant, oxidative stress and the biology of aging. Nature, 2000,408(9): 239-247.

[2]. J Hazim al-daraji, H A Al-Mashdani, A S Al-Hassani, H A Mirza, W K Al-Hayani, The Influence of Parsley (Petroselinum crispum)as feed Additive on Hematological Traits of local Iraqi Geese, advance in Nutrition research, Adv Nutr Res, 1(1) 2012, 15 .

[3]. M Lopez G, I R Sanchez-Medoza and N Ochoa- Alejo, . Compartive studies of volatile components and fatty acid of plants and in vitro cultures of parsley (Petroselinium crispum) (mill) nym ex hill) Journal of Food protection, 47, 1999, $3292-3296$.

[4]. Wong PYYand D D Kitts, Studies on the dual antioxidant and antibacterial properties of parsley (Petroselinium crispum) and cilantro (coriandrum sativum) extracts. Food Chemistry, 97, 2006,505-515.

[5]. S I kreydiyyeh, J Uste, I Kouk and R Al-sadi , The mechanism underlying the laxative properties of parsley extracts. Phytomedicine, 8,2001,382-388

[6]. S E Nielsen, J F Young, B Daneshvar, S T Lauridsen, P Knuthsen, and B Sandstrom, Effect of parsley intake on urinary apigenin excresion, blood antioxidant enzymes, and biomarkers for oxidative stress in human subjects. British journal of nutrition. $81,1999,447-455$.

[7]. M M Manderfeld, H W Schfer, P M Davidson, and E A Zottola, Isolation and identification of antimicrobial furocoum-arnis from parsley. Journal of food protection, 60, 1997,:72-77

[8]. Ozsoy- sacan, O, R Yanardag, H Orak, Y Ozgey, A Yarat and T Tunali Effects of Parsley (Petroselinium crispum) extracts versus glibornuride on the liver of streptozotocin-induced diabetic rats, J Ethnopharmcol, 104 (1-2) ,2006, 175 -181

[9]. Majid Goodarzi1, Nasir Landy2, Shahram Nanekarani, Effect of onion (Allium cepa L.) as an antibiotic growth promoter substitution on performance, immune responses and serum biochemical parameters in broiler chicks Vol.5, No.8, 2013.1210-1215

[10]. J Cheel , C Theoduloz, J Rodriguez, G Schmeda- Hirschmann, Free radical scavengers and antioxidants from lemongrass (Cymbopogon citrates). Journal of Agricultural food chemistry. 53,2005, 2511-2517.

[11]. K P Huynh , J Maridable, P Gaspillo, M Hasika, R Malauna, J Kawasaki Essential oil from Lemongrass extracted by supercritical carbon dioxide and steam distillation. The Philippine Agricultural Science,91,2008, 36-41.

[12]. F R Martin, M J Frutos, J A Perez-Alvarez, F Martinez-Sanches, J A Tel Rio , Flavonoids as neutraceutical, structural related antioxidant properties and their role on ascorbic acid preservation. In:Atta-Ur-Rahman (Ed) studies in natural products chemistry, 262002,324-389, Amesterdam, Elservier science.

[13]. D.C. Cannon,., Olitzky,I. \&Inkpen, J.A, in: Clinical Chemistry: Principles and Technics (Henry R.J.,Cannon, D.C.\& Winkelman,J.W.,eds>) 2nd.ed., .1974, .465-470. Harpers and Row, Hagerstown.

[14]. B.T Doumas,., Watson, W.A. and Biggs, H.G.,. Clin Chem Acta 31,1971, 87-96,

[15]. W Richmond, Preparation and properties of a cholesterol oxidase from Nocordia sp . and its application to the enzymatic assay of total cholesterol in serum . Clin .Chem ., 19, 1973,: 1350-1356.

[16]. WT Friedewald, Estimation of the Concentration of LowDensityLipoprotein Cholesterolin Plasma, Without Use of the Preparative Ultracentrifuge. Clin.Chem. U.S. 18,1972, 499.

[17]. G Bucolo and David H, Quantitative determination of serum triglycerides by the use of the enzymes.Clin.Chem. 19, 1973,: 475

[18]. J Hazim. Al-Daraji, H. A. Al-Mashadani, H. A. Mirza, A. S. Al-Hassani, W. K. Al-Hayani, The effect of utilization of parsley (Petroselinum crispum) in local Iraqi geese diets on blood biochemistry. Journal of American Science mericanscience 8, 2012,$8 ; 22$.

[19]. J Rabia. Abbas, Effect of Using Fenugreek, Parsley and Sweet Basil Seeds as Feed Additives on the Performance of Broiler Chickens. International Journal of Poultry Science 9 (3) 2010, 278-282

[20]. Vasko Gerzilov, Aleksandar Nikolo, Petar Petrov, Nadya Bozakova,George Penchev, Atanas Bochukov , Effect of a Dietary Herbal Mixture Supplement on the Growth Performance, Egg Production and Health status in Chickens. Journal of Central European Agriculture, 16(2), 2015.10-2

[21]. Maysoon Rodhan Jaffer . The effect of mixture of thyme and parsley in the diet on performance of broiler. Global Jour. Of bio-Sci and Biotechnology, VOL.2 (3) 2013, 390-392.

[22]. P Suresh Babu, and Srinivasan, K. , Influence of dietary capaicin and onion on the metabolic abnormalities associated with streptozotocin induced diabetes mellitus. Molecular and Cellular Biochemistry, 175, 1997, 49-57.

[23]. Saber Khodaei Ashan Influence of two herbal extracts on performance, carcass quality and blood parameters in broiler chicken. Annals of Biological Research, 2011, 2 (5) ,2011, 584-588.

[24]. Akiba A, Matsumoto T. Effects of dietary fibers on lipid metabolism in liver and adipose tissue in chicks. Journal of Nutrition, $112,1982.1577-1585$.

[25]. A Zargari, Medical plants. Second edition. Tehran University Press. 2001, 25-36. 